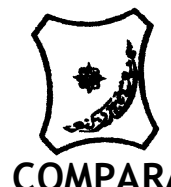

Bayero Journal of Pure and Applied Sciences, 10(1): 265 - 271

ISSN 2006 - 6996

\title{
COMPARATIVE YIELD AND CHARACTERIZATION OF FLAVONOIDS FROM THE STEM BACK AND ROOT OF Blighia sapida
}

\author{
"Yagana B. Abba, Abubakar G. Salisu and Rukaiyat, M. Said \\ Department of Applied Science, Kaduna Polytechnic, Kaduna, Nigeria \\ ${ }^{*}$ Correspondence author: yaganababaabba@gmail.com
}

ABSTRACT

Flavonoids represent a wide spread group of water soluble phenolic derivatives, known for their medicinal effect. This paper is focused on identifying the functional groups present in flavonoids of Blighia sapida stem bark and root sample. The percentage yield was higher with methanol extract of the stem bark compared to the root. The GC-MS of methanol extract shows carboxylic acid which might be attributed to presence of lipids. The isolation of flavonoids by $T L C$ and the FITR revealed the functional group $-\mathrm{OH}, \mathrm{C}=\mathrm{O}, \mathrm{CH}$ which are majorly responsible for the medicinal effect.

Key words: Blighia sapida, characterization, comparative yield, Flavonoids, methanol extract.

\section{INTRODUCTION}

Flavonoids represent a very wide - spread group of water - soluble phenolic derivatives, many of which are brightly coloured, being red, crimson, purple or yellow (Harbone, 1980). Flavonoids are characteristically plant products that are found in all groups (chromoplast, vacuole and chloroplast) except algae, bacteria and fungi (Wong, 1976). Their occurrences in insects, in the wings of number of butterflies, is due to their ingestion in food and inabilities of the catapillars to metabolise them. All animals above insects, breakdown the dietary flavonoids into small fragments which are then excreted in urine (Wong, 1976). Flavonoids have the C6 - C3 - C6 general structural backbone in which the two $\mathrm{C} 6$ units (Ring $A$ and Ring B) are of phenolic nature as shown in figure 1 . Due to the hydroxylation pattern and variation in the chromane ring (Ring C), flavonoids can be further divided into different subgroups such as anthocyanins, flavanols, flavanones, flavanonol, isoflavonoids and anthoxanthins shown in figure 2 (McCallum 2009). While vast majority of the flavonoids have their Ring $B$ attached to the $C 2$ position of Ring C, some flavonoids such as isoflavones, whose Ring $\mathrm{B}$ is connected at the $\mathrm{C} 3$ and $\mathrm{C} 4$ position of Ring $C$ is also found in plants. These basic structures of flavonoids are aglycones; however in plants, most of these compounds exist as glycosides. Biological activities of these compounds, include antioxidant activity, depending on the structural difference and the glycosylation pattern. Sermakkani and Thangapandian (2012) reported Cassia italic leaf methanol extract analysis using Gas Chromatography-Mass Spectrometry, revealed the presence of 17 compounds. In GCMS analysis, some of the phytocomponents screened were Phytol, Squalene and $n$ Hexadecanoic acid. The compounds were identified by comparing their retention time and peak area with that of literature and by interpretation of mass spectra. Many of them are used in industry for various applications like flavor, antioxidant, anti-inflammatory, antimicrobial, pesticide and cancer preventive. JiushiLiu, et al. (2014) reported. a reliable method for comprehensive chemical analysis of flavonoids in Nelumbinis stamen by HPLC-DADMS. The extraction protocol of flavonoids from Nelumbinis stamen was optimized by an orthogonal design. The chromatographic conditions were optimized, which exhibited similar level than that of the UHPLC platform allowing target compound identification in a shorter time with little solvent consumption. Moreover, similarity analysis, hierarchical clustering analysis and principal components analysis were successfully applied to demonstrate the variability of these Nelumbinis stamen samples. Similarly Isam, et al. (2016) reported the tannins of mature fruits extract of Acacia nilotica were identified by using Thin Layer Chromatography (TLC), Ultraviolet and Infrared spectroscopy. Comparisons of absorption spectra and TLC of the reference tannins and some phenolics with that of Acacia nilotica extracts revealed the presence of both condensed and hydrolyzable tannins, since it consists of catechin, tannic and gallic acids. Catechin considered to be the phenolic precursor of condensed tannins. Hydrolysis of Acacia nilotica extract, tannic and gallic acids by butanolic-hydrochloric acid yielded gallic acid which is considered to be a chemical precursor of hydrolyzable tannins. 


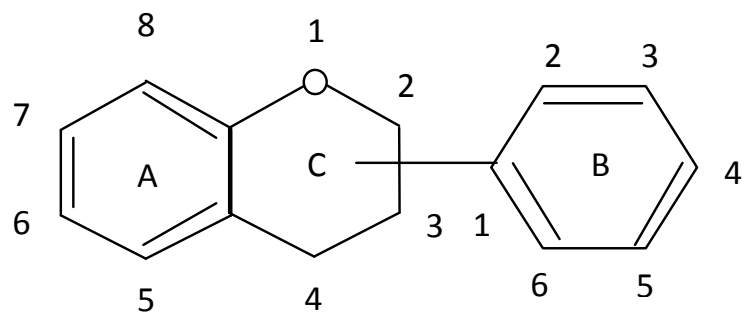

Figure 1.0: Flavonoid structure showing positions of carbon on the three rings as A B and $\mathrm{C}$<smiles>O[C@H]1Cc2ccccc2O[C@H]1c1ccccc1</smiles>

flavan-3-ols
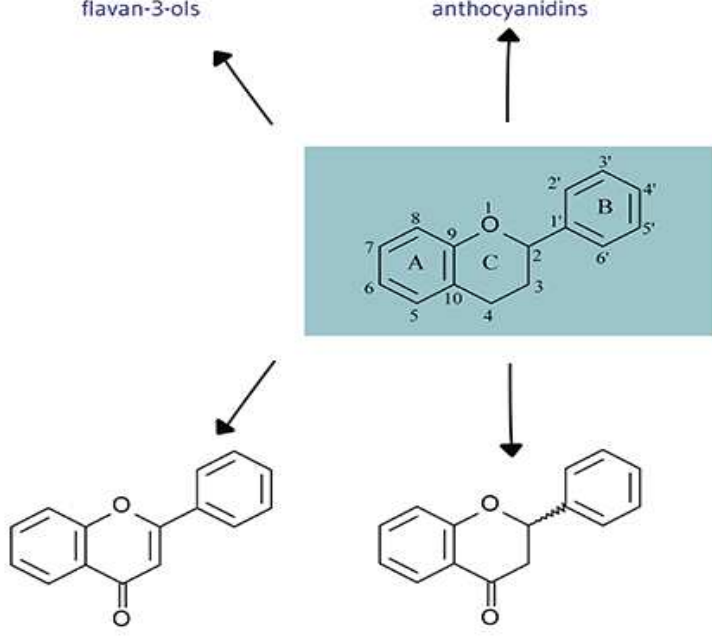

flavones

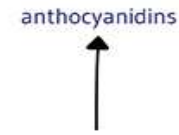<smiles>O=c1oc2ccccc2cc1-c1ccccc1</smiles><smiles>C[12CH2]</smiles><smiles>O=C1CC(c2ccccc2)Oc2ccccc21</smiles>

flavanones<smiles>O=c1c(O)c(-c2ccccc2)oc2ccccc12</smiles>

flavonols<smiles>CCCCC</smiles><smiles>C[12CH3]</smiles><smiles>O=c1c(-c2ccccc2)coc2ccccc12</smiles>

isoflavones

Figure 2: Structures of Flavonoid subclasses

Blighia sapida also known as "Ackee apple" belongs to the family called sapindaceae and it is noted for its highly distinctive reddish fruit. There are different species of the plant which include: Blighia sapida, Blighia welwitehi and Blighiaunijuate (Keay, 1999). It is known locally as "Isin" in Yoruba, "Gwanja kusa" in Hausa and "Okpu" in Igbo languages. The plant is about $25 \mathrm{~m}$ high and $2.5 \mathrm{~m}$ in growth, with heavy ever green crown. The bark is pale brown, while the leave have a stout stalk of about $5-15 \mathrm{~cm}$ long. The leaflets, $5-15 \mathrm{~cm}$ long by $3.5-7.5 \mathrm{~cm}$ broad. Flowering of the plant begin October - March. The seed is covered with a glossy testa and about $25 \mathrm{~cm}$ long by $2 \mathrm{~cm}$ broad, while the aril (i.e the edible part of the fruit) is pale yellow or cream coloured (Keay, 1999). Blighia sapida is a native sapida of West Africa. It extends from Senegal to Gabon. It is well distributed throughout Nigeria and found in drier forest of the savannah region (Esaoso and Odetokun, 2005). This work is focused on comparative yield and characterisation of flavonoid in the stembark and root extract of Blighia sapida through thin layer chromatography isolation. The methanol extract will be analysed through the use of fourier transform infrared and GC-MS spectra techniques.

\section{MATERIALS AND METHODS}

Collection of Plant Materials

Fresh stem bark and root of Blighia sapida were collected from Rimi College, Unguwan Rimi Kaduna. The specimens were identified and authenticated by the Biology Section in the Department of Applied Science, Kaduna Polytechnic.

Processing of plant samples

The stem bark and root of Blighia sapida were washed with clean water and air dried for 14 days at room temperature to reduce moisture content. The samples were pulverized into powder respectively using clean mortar and pestle, according to (Saidu et al 2012). 
Extraction of the plant samples

$300 \mathrm{~g}$ of each specimen (stem bark and root) were defatted for $48 \mathrm{hrs}$ using $1000 \mathrm{ml}$ of $\mathrm{n}$ hexane for each specimen at room temperature using cold maceration technique with agitation three times a day to enhance extraction. The extracts were filtered out respectively using No 1 Whatmann filter paper. The filtrates from each specimen was concentrated by evaporating to dryness using a rotary evaporator and stored properly. The dried marc were respectively further extracted with $1000 \mathrm{ml}$ of methanol using cold maceration technique for $48 \mathrm{hrs}$ with agitation three times a day. The extracts were filtered using No 1 whattmann filter paper. The filtrates were concentrated by evaporating to dryness using a rotary evaporator RE $52 \mathrm{~A}$ model at $65^{\circ} \mathrm{C}$, as reported (Saidu et al 2012).

Gas Chromatography- Mass Spectra (GCMS) Analysis of the Methanol Extract of the Stem Bark and Root of Blighia sapida samples The analysis of the methanol extracts of the samples were carried out using GC-MS with (model no QP 2010 plus Shimadzu, Japan), with a column oven temperature $\left(80^{\circ} \mathrm{C}\right)$, injection temperature and mode $\left(250^{\circ} \mathrm{C}\right.$ and split), flow control mode linear velocity, pressure $(108.0 \mathrm{Kpa})$ and column flow of $1.58 \mathrm{ml} / \mathrm{min}$ according to Sermakkani and Thangapandian (2012).

Fractionation of the methanol extract of the plant sample

The methanol extract from each plant specimen was dissolved in distilled water $200 \mathrm{ml}$ and partitioned with diethyl ether $(200 \mathrm{ml})$ in a column to obtain the aqueous portion and the diethyl ether portion. The aqueous portions were further partitioned respectively with of $n$ butano $200 \mathrm{ml}$ to obtain the butanol portion and aqueous portion. The n-butanol portion obtained was partitioned with potassium hydroxide $(1 \%, 200 \mathrm{ml})$. The potassium hydroxide portions obtained were further partitioned with $n$-butanol $(200 \mathrm{ml})$ and dilute hydrochloric acid. The percentage yield of each extract and fraction was obtained using eqt 1 as reported (Sermakkani and Thangapandian 2012).

$\%$ yield $=\frac{\text { weight of extract } x 100}{\text { weight of sample }}$

t1

Preparative Thin Layer Chromatography (PTLC) of the n-Butanol Fractions of the Stem Bark and Root

The n-butanol portion obtained containing mixtures of fluorides were then subjected to preparative thin layer chromatography (PTLC) using the solvent system $\left(\mathrm{CHC1}_{3}: \mathrm{CH}_{3} \mathrm{OH}: \mathrm{H}_{2} \mathrm{O}\right)$ at (3:3:1) respectively. The plates were allowed to dry for some few minutes and sprayed with $10 \%$ tetraoxosulphate (VI) acid and placed in an oven to facilitate drying. The plates with two prominent spots were scrapped off the bark of the plates and dissolved in small quantity of acetone and then filtered. The filtrates were further centrifuged to obtain clear filtrates which were decanted and concentrated. The thin layer chromatograph of the isolates were obtained on single spots on each plate. The plates were allowed to dry and then sprayed with $10 \%$ tetraoxosulphate (VI) acid and oven dried. Finally the isolates were subjected to Fourier transform infrared spectroscopy (FTIR) analysis (Isam, et al. 2016).

Fourier Transform Infrared Spectroscopic (FTIR) Analysis of Samples Extracts

The isolates obtained from the $n$-butanol extracts were subjected to infrared Spectroscopic analysis recorded between wave number $4500-4000 \mathrm{~cm}^{-1}$ using SHIMADZU FTIR$8400 \mathrm{~S}$ as reported Isam, et al. (2016).

\section{RESULTS AND DISCUSSION}

Extraction Yield (\%)

The percentage yield of the $n$-hexane and methanol extracts of the stem bark and root of Blighia sapida and their aqueous, diethylether, $\mathrm{n}$-butanol and potassium hydroxide fractions. The percentage yield of the methanol extract for the stem bark was higher with a value of $24 \%$ and $17.4 \%$ for the root as shown in the table 1 and 2 respectively.

Table 1: \% Yield of Extract from Stem-Bark of Blighia sapida

\begin{tabular}{lcl}
\hline Extract Fraction & Weight $(\mathrm{g})$ & Yield $(\%)$ \\
\hline $\mathrm{N}-$ hexane $(\mathrm{e})$ & 15.1 & 5.04 \\
Methanol (e) & 72.2 & 24.0 \\
Aqueous (f) & 2.53 & 3.51 \\
Diethyl ether (f) & 0.350 & 0.484 \\
N- butanol (f) & 1.96 & 2.72 \\
Potassium hydroxide (f) & 0.574 & 0.794
\end{tabular}

Key, $e=$ extract, $f=$ fraction 
Table 2: \% Yield of Extract from Root of Blighia sapida

\begin{tabular}{lcc}
\hline Extract Fraction & Weight (g) & Yield (\%) \\
\hline $\mathrm{N}-$ hexane(e) & 19.5 & 6.43 \\
Methanol (e) & 52.2 & 17.4 \\
Aqueous (f) & 1.91 & 3.65 \\
Diethyl ether (f) & 0.168 & 0.321 \\
N- butanol(f) & 1.76 & 3.36 \\
Potassium hydroxide (f) & 0.720 & 1.38 \\
\hline
\end{tabular}

KEY, $e=$ extract, $f=$ fraction

The GC-MS spectrum confirmed the presence of various components with different retention times. The mass spectrometer analyses the compounds eluted at different times to identify the nature and structure of the compounds. The large compound fragments into small compounds giving rise to appearance of peaks at different $\mathrm{m} / \mathrm{z}$ ratios. These mass spectra are fingerprint of that compound which can be identified from the data library as reported by Shadkami et al. (2009). The GC-MS analysis of the methanol extract of Blighia sapida stem bark and root lead to the identification of a number of compounds. These various compounds present are shown in tables 3 and 4 as, 1-Decane carboxylic acid, 1Pentadecan carboxylic acid, Methyl 14-Methyl pentadecanoate, 1-pentadecanecarboxylic, Methyl trans, trans 9,12-octadecadienoic acid, Methyl. 11-octadeceonoate, Cis9Ocatadecenoic, n-Octadecanoic acid, Cis-13Docodenoic acid, 1-flourodecane, 1pentadecanecarboxylic acid, 10-Undecyclene
Aldehyde, 2,3-Dihydroxy propyl Palmitate and2(1-Methy-2-Oxohydazino) benzonitrile, Methy17-methyl cyclo-penta (c) pyran-4carbohydrate, 2,5- Dimethoxy Cinnamic acid, nHexadecanoic acid, methyl ester, 1pertadecane Carboxylic acid, Methy1 trans-9Octadecenoate, Cis-9-octadecanioc Acid, 3,7Dimethy1-6-Octan-3-ol, Cis-13-Docosenamide, respectively. The composition determined for this methanolic extract corresponds to $79.47 \%$ and $92.63 \%$ respectively of the entire GC-MS chromatogram. Most of the compound detected by the GC - MS are carboxylic acids. This might be attributed to the presence of lipids from the extracts which may involve clean up steps to release phenols from the glycoside and ester bonds in enzymatic alkaline and acidic medium as reported by Liggins et al. (1998). However, the difficulties of flavonoid glycoside evaluation could be solved when high temperature - high resolution GC-MS is applied (Pereira et al. 2004).

Table 3: GC-MS of Methanol Extract for Stem bark of Blighia sapida

\begin{tabular}{llllll}
\hline IUPAC NAME & MOLECULAR & MOLAR & R.T(S) & $\%$ & $\%$ \\
& FORMULAR & MASS $\left(\mathrm{gmol}^{-1}\right)$ & & AREA & COMPOSITION \\
1-Decane carboxylicacid & $\mathrm{C}_{11} \mathrm{H}_{22} \mathrm{O}_{2}$ & 186 & 14.218 & 1.66 & 1.46 \\
1-Pentadecan carboxylic acid & $\mathrm{C}_{16} \mathrm{H}_{32} \mathrm{O}_{2}$ & 256 & 14.218 & 1.66 & 1.53 \\
& & & & & \\
Methyl 14-Methyl & $\mathrm{C}_{17} \mathrm{H}_{34} \mathrm{O}_{2}$ & & & & \\
pentadecanoate & $\mathrm{C}_{16} \mathrm{H}_{32} \mathrm{O}_{2}$ & 270 & 16.851 & 1.81 & 4.19 \\
$\begin{array}{l}\text { 1-pentadecanecarboxylic } \\
\text { Methyl trans, trans }\end{array}$ & $\mathrm{C}_{19} \mathrm{H}_{34} \mathrm{O}_{2}$ & 256 & & & \\
octadecadienoic acid & $9,12-$ & & & & 2.27 \\
Methyl. 11-octadeceonoate & & & & & \\
Cis9-Ocatadecenoic & $\mathrm{C}_{19} \mathrm{H}_{36} \mathrm{O}_{2}$ & 294 & 19.877 & 1.32 & 1.95 \\
n-Octadecanoic acid & $\mathrm{C}_{18} \mathrm{H}_{34} \mathrm{O}_{2}$ & 296 & 19.968 & 2.89 & 3.67 \\
Cis-13-Docodenoic acid & $\mathrm{C}_{18} \mathrm{H}_{36} \mathrm{O}_{2}$ & 282 & 20.825 & 46.47 & 30.22 \\
1-flourodecane & $\mathrm{C}_{22} \mathrm{H}_{42} \mathrm{O}_{2}$ & 284 & 21.061 & 8.60 & 6.81 \\
1-pentadecanecarboxylic & $\mathrm{C}_{10} \mathrm{H}_{21} \mathrm{~F}$ & 338 & 22.042 & 1.85 & 6.16 \\
10-Undecyclene & $\mathrm{C}_{16} \mathrm{H}_{32} \mathrm{O}_{2}$ & 160 & 22.440 & 1.85 & 6.17 \\
Aldehyde & $\mathrm{C}_{11} \mathrm{H}_{20} \mathrm{O}$ & 256 & 23.271 & 3.12 & 7.82 \\
& & & 24,208 & 3.03 & 6.62 \\
2,3-Dihydroxy propyl & & 168 & & & \\
Palmitate & $\mathrm{C}_{19} \mathrm{H}_{38} \mathrm{O}_{4}$ & & & & \\
\hline
\end{tabular}


Special Conference Edition, November, 2017

Table 4: GC-MS of Methanol Extract for Root ofBlighiasapida

\begin{tabular}{|c|c|c|c|c|c|}
\hline IUPAC NAME & $\begin{array}{l}\text { MOLECULAR } \\
\text { FORMULAR }\end{array}$ & $\begin{array}{l}\text { MOLAR MASS } \\
\left(\mathrm{gmol}^{-1}\right)\end{array}$ & R.T(S) & $\begin{array}{l}\% \\
\text { AREA }\end{array}$ & $\begin{array}{l}\% \\
\text { COMPOSITION }\end{array}$ \\
\hline $\begin{array}{l}\text { 2-(1-Methy-2- } \\
\text { Oxohydazino) } \\
\text { benzonitrile }\end{array}$ & $\mathrm{C}_{8} \mathrm{H}_{7} \mathrm{~N}_{3} \mathrm{O}$ & 161 & 14.542 & 7.20 & 3.23 \\
\hline $\begin{array}{l}\text { Methy17-methyl cyclo- } \\
\text { penta(c) pyran-4- } \\
\text { carbohydrate }\end{array}$ & $\mathrm{C}_{11} \mathrm{H}_{11} \mathrm{O}_{3}$ & 190 & 14.725 & 47.95 & 39.68 \\
\hline $\begin{array}{l}\text { 2,5- Dimethoxy } \\
\text { Cinnamic acid }\end{array}$ & $\mathrm{C}_{11} \mathrm{H}_{12} \mathrm{O}_{4}$ & 208 & 15.382 & 10.70 & 10.06 \\
\hline $\begin{array}{l}\mathrm{n} \text {-Hexadecanoic acid } \\
\text { methyl ester }\end{array}$ & $\mathrm{C}_{17} \mathrm{H}_{34} \mathrm{O}_{2}$ & 270 & 19.075 & 2.31 & 4.95 \\
\hline $\begin{array}{l}\text { 1-pentadecane } \\
\text { Carboxylic acid }\end{array}$ & $\mathrm{C}_{16} \mathrm{H}_{32} \mathrm{O}_{2}$ & 256 & 20,439 & 6.59 & 5.42 \\
\hline $\begin{array}{l}\text { Methy1 trans-9- } \\
\text { Octadecenoate }\end{array}$ & $\mathrm{C}_{19} \mathrm{H}_{36} \mathrm{O}_{2}$ & 296 & 22.315 & 3.28 & 15.21 \\
\hline \multirow{3}{*}{$\begin{array}{l}\text { Cis-9-octadecanioc } \\
\text { Acid } \\
\text { 3,7-Dimethy1-6- } \\
\text { Octan-3-ol } \\
\text { Cis-13-Docosenamide }\end{array}$} & $\mathrm{C}_{18} \mathrm{H}_{34} \mathrm{O}_{2}$ & 282 & 23.325 & 15.98 & 4.26 \\
\hline & $\mathrm{C}_{10} \mathrm{H}_{20} \mathrm{O}$ & 156 & 28.387 & 3.00 & 5.20 \\
\hline & $\mathrm{C}_{22} \mathrm{H}_{43} \mathrm{NO}$ & 337 & 29.09 & 2.97 & 4.62 \\
\hline
\end{tabular}

The TLC result shows that when the extract was run through, it gave two fractions with the presence of yellow spots with $\mathrm{Rf}$ values as shown on table 5 indicates that flavonoids were successfully isolated by Preparative Thin Layer Chromotography (PTLC) as reported Burda,
(2001). The two fractions of the extract on TLC were scratched and taken separately, the composition of the fractions was investigated by FTIR tests to identify their nature or property.

Table 5:Retention factor (RF) values of isolated flavonoids

\begin{tabular}{lllll}
\hline Plant extract & $\begin{array}{l}\text { Distance moved by } \\
\text { solute }(\mathrm{cm})\end{array}$ & $\begin{array}{l}\text { Distance moved by } \\
\text { solvent }(\mathrm{cm})\end{array}$ & $\begin{array}{l}\text { Retention } \\
\text { factor }\end{array}$ & Colour \\
Stem bark & 3.40 & 4.5 & 0.77 & Yellow \\
Root & 3.1 & 4.6 & 0.64 & yellow \\
\hline
\end{tabular}

The FTIR absorption spectra show the presence of $-\mathrm{C}=\mathrm{C}: \mathrm{C}-\mathrm{H}$ bend, $=\mathrm{C}-\mathrm{H}$ bend, $-\mathrm{C}-\mathrm{O}$ stretch, $=\mathrm{C}-$ $\mathrm{O}-\mathrm{C}$ stretch, $\mathrm{CH}_{3} \mathrm{CH}$ bend, $\mathrm{C}-\mathrm{H}$ bend, $\mathrm{N}-\mathrm{H}$ bend, $\mathrm{C}=\mathrm{O}$ stretch, $\mathrm{C}-\mathrm{H}$ stretch, $\mathrm{O}-\mathrm{H}$ stretch, of isolated flavonoid from stem- bark of Blighia sapida presented in table 6 and $\mathrm{C}$ - $\mathrm{O}$ stretch, $\mathrm{C}$ - N Stretch, =C-O-stretch, $\mathrm{N}-\mathrm{H}$ bend, $\mathrm{C}=\mathrm{O}$ stretch, C-H stretch, O-H Stretch-bonded, $\mathrm{O}-\mathrm{H}$ stretch, H-bonded, of isolated flavonoid from root of Blighia sapida presented in table 7 similar to reports of Isam et al. (2016). In both tables, the spectra confirmed the presence of functional groups $(\mathrm{CH}, \mathrm{OH}, \mathrm{C}=\mathrm{O})$ for flavonoids which is a polyphenoids which are widely reported for their antioxidant potential, antibacterial, antifungal, etc. as reported by Burda, (2000). 
Table 6: Absorption band for the infrared spectroscopy of isolated flavonoid from stem- bark of Blighia sapida

\begin{tabular}{llll}
\hline PEAK VALUE $(\mathrm{CM})$ & ABSORPTION $\left(\mathrm{CM}^{-1}\right)$ & $\begin{array}{l}\text { FUNCTIONAL } \\
\text { GROUP }\end{array}$ & REMARKS \\
& & \\
635.57 & $700-610(\mathrm{~b} . \mathrm{s})$ & $-\mathrm{C}=\mathrm{C}: \mathrm{C}-\mathrm{H}$ bend & Alkynes \\
960.58 & $650-1000(\mathrm{~s})$ & $\mathrm{C}-\mathrm{H}$ bend & Alkynes \\
1057.99 & $1050-1085(\mathrm{~m}, \mathrm{~s})$ & $-\mathrm{C}-\mathrm{O}$ stretch & Alcohol \\
1243.16 & $1200-1275(\mathrm{~m}-\mathrm{s})$ & $=\mathrm{C}-\mathrm{O}-\mathrm{C}$ stretch & Alcohols, aromatics \\
1376.26 & $1370-1390(\mathrm{~m})$ & $\mathrm{CH}$ CH bend & Alkyls \\
1459.20 & $1450-1470(\mathrm{~s})$ & $\mathrm{C}-\mathrm{H}$ bend & Alkyls \\
1542.14 & $1510-1560(\mathrm{~m}-\mathrm{s})$ & $\mathrm{N}-\mathrm{H}$ bend & Amides \\
1762.03 & $1760-1790(\mathrm{~s})$ & $\mathrm{C}=\mathrm{O}$ stretch & Ester \\
3489.34 & $2850-3000(\mathrm{~s})$ & $\mathrm{C}-\mathrm{H}$ stretch & Alkanes \\
3744.22 & $2500-3500(\mathrm{~s}, \mathrm{~b})$ & $\mathrm{O}-\mathrm{H}$ stretch & Carboxylic acids \\
\hline
\end{tabular}

KEY: m=medium;

s=strong;

$\mathrm{b}=$ broad

Table 7:Absorption band for the infrared of isolated flavonoid from root of Blighia sapida

\begin{tabular}{|c|c|c|c|}
\hline PEAK VALUE (CM) & ABSORPTION $\left(\mathrm{CM}^{-1}\right)$ & FUNCTIONAL GROUP & REMARKS \\
\hline 1064.74 & $1050-1085(m-s)$ & C - O stretch & Alcohols \\
\hline 1163.11 & $1020-1250(\mathrm{~m})$ & C - N Stretch & $\begin{array}{l}\text { Aliphatic } \\
\text { amines }\end{array}$ \\
\hline 1271.13 & $1200-1275(\mathrm{~m}-\mathrm{s})$ & $=$ C-O-stretch & alcohol \\
\hline 1530.57 & $1570-1560(\mathrm{~m}-\mathrm{s})$ & $\mathrm{N}-\mathrm{H}$ bend & amides \\
\hline 1652.09 & $1630-1680(\mathrm{~m}-\mathrm{s})$ & $C=0$ stretch & Amides \\
\hline 2929.97 & $\begin{array}{l}2850-300 \\
\text { (s) }\end{array}$ & $\mathrm{C}-\mathrm{H}$ stretch & Alkanes \\
\hline 3463.30 & $3200-3500(b, s)$ & $\mathrm{O}-\mathrm{H}$ Stretch-bonded & $\begin{array}{l}\text { Alcohols, } \\
\text { phenol }\end{array}$ \\
\hline 3476.81 & $3200-3500$ & $\mathrm{O}-\mathrm{H}$ stretch, $\mathrm{H}$-bonded & $\begin{array}{l}\text { Alcohols } \\
\text { phenols }\end{array}$ \\
\hline
\end{tabular}

KEY: $\mathrm{m}=$ medium; $\quad \mathrm{s}=$ strong $\quad \mathrm{b}=$ broad

CONCLUSION

The percentage yield of the methanol extract for the stem bark was higher with a value of $24 \%$ and $17.4 \%$ for the root. Most of the compound detected by the GC - MS are carboxylic acids, flavonoids were successfully isolated by Preparative Thin Layer Chromatography (PTLC), the FTIR spectra confirm the presence of functional groups $(\mathrm{CH}$, $\mathrm{OH}, \mathrm{C}=0$ ) for flavonoids.

The structural class, degree of hydroxylation, other substitutions, conjugation and degree of polymerization contribute to the health benefits of flavonoids.; Functional hydroxyl groups in flavonoids mediate their antioxidant

\section{REFERENCES}

Burda Oleszek W. (2001).Anti-oxidant and Antiradical Activities of Flavonoids.J., Agric. Food Chem. 49 (6) : 2774-2779

Esuoso, K.O, and Odetoun S.M., (2005). Proximate Chemical Composition and Possible Industrial Utilization of Blighia sapida Fuel and Oil. Journal of Phytotherapy Research. 72(7): 311-313.

Harbone, J. B., (1980). Plant Phenolics. In: Bella E.A Charlwood B.V. (eds) effects by scavenging free radicals or by chelating metal ions. The chelation of metals could be crucial in the prevention of radical generation which damage target bio molecules (Burda, 2001).

Further research on the stem bark and root of Blighia sapida should be carried out, to determine the different types of flavonoids present and also the total flavonoids content. Acknowledgement

The authors would want to express their profound appreciation to the National research institute for chemical technology Zaria, for using their laboratory where most of these work was conducted.

Encyclopedia of plant physiology, volume 8 secondary plant products springer-vorlage, Berlin Heidelberg New York pages 329-395.

Isam, E. Hussein, E. and Christina, Y. I. (2016). Methods for Extraction and Characterization of Tannins from Some Acacia Species of Sudan. Pak. J. Anal. Environ. Chem. 17 (1), 43 - 49 
JiushiLiu, YaojieGuo, JinZhang, YaodongQi, Xiaogu ang Jia, GangfengGao, JingaoShuai, Haita oLiu, BengangZhang,PeigenXiao. (2014), Systematic chemical analysis of flavonoids in the Nelumbinis stamen. Science direct, Phytomedicine 21,(13): 1753-1758

Keay, S.L (1999).Screening of some Nigerian plants for Mulluscidal Activity. Reveal Elevageet De medicine Veterinairedes pays Tropisaux (France) 44(1): 195-202

Liggins, J., Bluck, L. J., Coward, A., and Binghan, S. A (1998). Extraction and qualification of Daidzein and Aenistein in food. Anal Biochem. 264; 1-7

Kumar S, Pandey A.K. (2013). Chemistry and biological activities of flavonoids: an overview. Scientific World Journal.; 2013:162750

McCallum J., (2009) Chemistry of Flavonoids in Fruit and Vegetable phytochemicals; Chemistry, Nutritional Value and Stability, chapter 5, Blackwell publishing; Ames. 1A, USA page 131-153

Pereira, A.D.S; Padilha, M.C and Neto F.R.D.A (2004). Two decades of high temperature Gas Chromatography What 's next?" Microchem J. 77; 141-149

Saidu, A.N., Mann, A., and Onuegbu, C. D., (2012) Phytochemical Screening and Hypoglyceme effect of aqueous Blighia Sapida root bark extract on normoglycemic Albino rats, British journal of pharmaceutical research 2 (2): 89-97

Sermakkani, M. and Thangapandian V. (2012) Gc-Ms Analysis of Cassia Italica Leaf Methanol Extract. Asian Journal of Pharmaceutical and Clinical Research $5,(2)$.

Shadkami, F., Esterez S; andHellem R. (2009).Analysis of catechin and condensed tannins by thermally assisted hydrolysis, methylation. GC/MS and by a novel two step methylation. $J$. Anal. Appl. Pyrolysis. 85;54-65.

Wong, E., and Goodwin, T. W., (1976) Biosynthesis of Flavonoids in Chemistry and Biochemistry of plant pigments, vol. L $2^{\text {nd }}$ ed., page. $464-526$ 